\title{
Bioavailability index for quantitative evaluation of plant availability of extractable soil trace elements
}

\author{
Bin Chen, Xiao-quan Shan ${ }^{1}$ and Jin Qian \\ Research Center for Eco-Environmental Sciences, Academia Sinica, P.O. Box 2871, Beijing 100085, P. R. China. \\ 'Corresponding author*
}

Received 26 January 1996. Accepted in revised form 3 September 1996

Key words: bioavailability, chemical extraction, genotypical differences, plant nutrition, trace elements

\begin{abstract}
A new index, Bioavailability Index (BI) and the corresponding experimental method were developed for quantitative evaluation of bioavailability of the extractable soil trace elements. Soils were first treated with various extractants (DTPA, $\mathrm{HCl}, \mathrm{NH}_{2} \mathrm{OH} \cdot \mathrm{HCl}+\mathrm{HCl}$ ) separately to remove the extractable elements. The soils after extraction were washed with deionised water to eliminate the extractant and its $\mathrm{pH}$ was adjusted with $\mathrm{Ca} 0$ and finally restored to its original $\mathrm{pH}$ level. Wheat (Triticum aestivum L.) and rape (Brassica chinensis) were planted in the untreated and treated soils for 8 weeks. The concentrations of the trace elements in plants were determined after harvest. Nutrient accumulation by plants is significantly reduced due to removal of extractable trace elements from the soil. BI of the extractable fraction was proportional to the ratio of plant accumulation reduction to trace element extractability. In the present study, BI value of the total content of soil trace elements was designated as 1 . Though only a minor fraction of the total soil nutrient, generally less than 5\%, was removed by DTPA, the nutrient accumulation by plants, especially for wheat, was reduced greatly, leading to relatively large BI values. For wheat, the average $\mathrm{BI}$ values of the eight nutrients $\mathrm{Cu}, \mathrm{Mn}, \mathrm{Zn}, \mathrm{Ni}, \mathrm{Co}, \mathrm{Pb}, \mathrm{Cr}$, and $\mathrm{V}$ were found to be $22.7,17.6$ and 17.4 for the three testing soils, and for rape, the corresponding values of $8.9,10.0$ and 11.0 were obtained, indicating that the DTPA-extractable elements represent the highly available fraction of the total content. The BI values for $\mathrm{HCl}$-extractable elements were much lower compared with those for DTPA. For wheat, the average BI values for the three soils are 2.0,1.9 and 2.4, and for rape, the corresponding values are 4.8, 4.1 and 3.7. The high availability of DTPA-extractable trace elements and relatively low availability of $\mathrm{HCl}$-extractable trace elements highlight the significant role that chelation action might play in plant nutrient acquisition.

The different responses of wheat and rape to the soils previously subjected to the same extraction procedure could be explained by their genotypical differences in sensitivity to nutrient deficiencies. The quantitative nature of BI makes it valuable in the study of nutrient bioavailability and plant accumulation mechanisms.
\end{abstract}

Abbreviations: R-Correlation coefficients, BI-Bioavailability index

\section{Introduction}

Bioavailability of soil trace elements is of great concern both from agricultural and environmental standpoint. Some elements ( $\mathrm{Cu}, \mathrm{Mn}, \mathrm{Zn}$, etc.) are known to be essential for normal growth of crops, some other elements $(\mathrm{Cd}, \mathrm{Pb}, \mathrm{Cr}, \mathrm{Hg}$, etc.) are regarded as toxic elements due to their detrimental effect to human health.

\footnotetext{
* FAX No: +8801062555381
}

There exists great need to determine the bioavailability of these elements in soils (Hooda and Alloway, 1993; Xian and Shokohifard, 1989), to predict plant uptake of these elements (Alegria et al., 1991; He and Singh, 1994) and to test soils for their capacity to supply adequate nutrient elements to plants (Levesque and Mathur, 1988; Lindsay and Norvell, 1978).

It is well recognized that total content is not a satisfactory index for measuring element bioavailability, 
due to the different and complex distribution pattern of the element among various chemical species or solid phases in soils (Dudka and Chlopecka, 1990; Iyengar et al., 1981; Warden and Reisenauer, 1991). It is very desirable to determine or to define bioavailable functions from the total content and this task was partially achieved by chemical extraction methods. Up to date, numerous extraction methods have been proposed. Generally, these methods can be classified as single extraction or sequential extraction. In particular, single extraction was employed by many authors (Algeria et al., 1991; He and Singh, 1994; Hoyt and Nyborg, 1971; Levesque and Mathur, 1988; Salcedo and Ellis, 1979; Taylor et al., 1993).

There are many reports in the literature on the use of the correlation coefficients $(R)$ between extractable nutrient fractions and total plant content as a criterion of bioavailability. If the plant accumulation of an element is significantly correlated with its extractability, the extractable fraction of the elements is a good measure for plant availability. The higher the correlation coefficients is, the more suitable the extraction method should be. The correlation methods were also used to evaluate the suitability of a regression equation to predict plant accumulation from the extraction data. Generally, the two kinds of evaluation were performed simultaneously (Duangpatra et al., 1979; He et al., 1991; Khamparia et al., 1994; Randall et al., 1976; Salcedo and Ellis, 1979; Shuman and Anderson, 1974).

However, there are some drawbacks associated with the application of the correlation method. $R$ is useful as a qualitative criterion for evaluation of the suitability of an extractant or equation to predict nutrient accumulation by plant However, for several reasons, it cannot be regarded as a good quantitative index for measuring bioavailability of the extractable soil trace elements. First, single extractant is believed to be able to remove more available fractions of a trace element from the total soil content, therefore $\mathrm{R}$ between extractable fractions and plant content should be larger than that between total soil content and plant content of the element. But actually the opposite situations were often observed. In an investigation to ascertain the relationship between the metal content of soils in terms of total and extractable with EDTA and of vegetables grown on them, Alegria et al. (1991) found that the highest correlation values are those between the total content and uptake of $\mathrm{Ni}$ and $\mathrm{Cd}$ by vegetable species. Furthermore, correlation between extractable content of soils and total content of $\mathrm{Cd}$ in leaves or stems was found to be a negative one. Another research (Davies, 1992) revealed that $\mathrm{Pb}$ accumulation by radish can be best predicted by total soil $\mathrm{Pb}$ compared with other fractions such as exchangeable, specifically absorbed and organic bound.

Different extractants, of course, differ in their reaction mode, e.g. ion exchange, chelation, desorbing, mass action by $\mathrm{H}^{+}$, etc., and there is a great variation of the amount of metals extracted, which means the various extractable fractions should differ largely in availability. However, this kind of difference can hardly be differentiated by correlation method. $\mathrm{R}$ values between different extractable fractions and plant content of the trace elements were often found to be very similar (Duangpatra et al., 1979; Khamparia et al., 1994; Levesque and Mathur, 1988).

The last reason is related to the inherent nature of the statistic analysis itself, which needs a large number of soils to perform reliable correlation analysis. Correlation coefficient is an index of overall evaluation of all these soils, whereas the differences among soils cannot be distinguished. Trace element bioavailability is regulated by many factors, such as soil chemical and physical properties and plant type. The correlation method is not capable of investigating the specific nature of bioavailability of trace elements in a particular soil.

So it is clear that the information provided by correlation analysis is not adequate to probe into quantitative and specific nature of bioavailability, rather it should be regarded as a qualitative criterion for evaluation of nutrient accumulation by plant. In this study, we attempt to develop a new index, hereafter named bioavailability index (BI), to assist understanding of the quantitative aspect of bioavailability of the extractable soil trace elements.

\section{Basic considerations for bioavailability index}

The bioavailability index and the corresponding experimental method are designed based on the following considerations. The extractable trace elements generally represent the readily available fraction of the elements in soils, and the remaining fraction after extraction will be relatively marginally available for plants. Therefore, removal of the extractable fraction means plant grown in the soil will suffer from a certain degree of nutrient deficiency and reductions in total plant content of the trace elements could occur. The ratio of the plant accumulation reduction to trace element 
extractability can be used to estimate the bioavailability index of the extractable fraction. BI is calculated according to the following procedure.

Soils were first extracted with a certain extractant. After extraction, the mixture was subjected to suctioned filtration to recover the soil. The soil was washed with distilled-deionized water several times to remove the extractant completely. The extraction and washing procedure may give rise to changes of some chemical and physical properties of the soil. Among the many soil properties governing trace element bioavailability, soil $\mathrm{pH}$ is the most important one which received extensive investigations (Davies, 1992; Eriksson, 1989; Sauerbeck, 1991; Xian and Shokohifard, 1989), whereas other factors seem to be of minor significance. Therefore, $\mathrm{pH}$ adjustment was performed after washing to make the treated soils have their original $\mathrm{pH}$ level.

Besides the trace elements investigated, the available forms of other nutrients will also be removed by the extractions. Plant growth may be seriously limited due to nutrient deficiency and hence influences uptake of the trace elements. To minimize this effect, all soils, treated and untreated, were fertilized with sufficient amount of the most important macro-nutrients $N, P, K$ and $S$ before potting. After soil preparation, the testing crops were planted in both the treated and untreated soils under the same experimental conditions. After harvest, the plant tissues were analyzed for trace metal concentrations. BI of the extractable fraction of a trace element can be calculated by the following formula:

$$
\mathrm{BI}=\frac{\mathrm{C}_{\mathrm{P}}^{\mathrm{O}}-\mathrm{C}_{\mathrm{p}}^{\prime}}{\mathrm{C}_{\mathrm{e}}}=\frac{\Delta \mathrm{C}_{\mathrm{P}}}{\mathrm{C}_{\mathrm{e}}}
$$

where

$\mathrm{C}_{\mathrm{p}}^{0}=$ tissue content of the trace element in the testing crop planted in the untreated soil

$\mathrm{C}_{\mathrm{p}}^{\prime}=$ tissue content of the trace element in the testing crop planted in the treated soil

$\mathrm{C}_{\mathrm{e}}=$ extractable content of the trace element

Bioavailability index is a relative concept. The significance of $\mathrm{BI}$ obtained by the above formula cannot be clearly understood if $\Delta C_{p}$ and $C_{e}$ were expressed as absolute content (e.g. $\mu \mathrm{g} \mathrm{g}^{-1}$ ). The trouble lies also in the wide variations of plant nutrient accumulation in different soils and by different plants, which make the direct comparison of $\Delta \mathrm{C}_{\mathrm{p}} / \mathrm{C}_{\mathrm{e}}$ quite difficult. To unify the significance of $\mathrm{BI}$ and facilitate comparison, a relative method is adopted to calculate BI. $\mathrm{C}_{\mathrm{e}}$ is expressed as a proportion of the total content of the trace element $\left(C_{t}\right)$ in the untreated soil, and $\triangle C p$ is expressed as a proportion of $C_{p}^{0}$. Because what is concerned is bioavailability of the extractable fraction relative to the total content of a trace element in soils, BI of the total content in the untreated soil is designated as 1 , regardless of trace elements, soils, or plants. This means that $100 \%$ of the total content of trace elements in soil is recognized as a nutrient pool for the plants grown in it. In order to make BI comparable the calculation of BI values is based on the total content of trace elements in the untreated soils although plants grown in the previously treated soils are never exposed to soil with total nutrient. The relative $\mathrm{BI}$ of the extractable fraction can be calculated as following:

$$
\mathrm{BI}=\frac{\Delta \mathrm{C}_{\mathrm{P}} / \mathrm{C}_{\mathrm{P}}^{0}}{\mathrm{C}_{\mathrm{e}} / \mathrm{C}_{\mathrm{t}}}
$$

If $\mathrm{C}_{\mathrm{e}}$ accounts for only $1 \%$ of $\mathrm{C}_{\mathrm{t}}$, and removal of $\mathrm{C}_{\mathrm{e}}$ causes a plant accumulation reduction accounting for $10 \%$ of $\mathrm{C}_{\mathrm{p}}^{0}$, then the calculated $\mathrm{BI}$ is 10 , in this case BI value of the extractable fraction is 10 times of that of the total content of the trace element in the untreated soil. In this way the quantitative significance of $\mathrm{BI}$ is established and comparison of different $\mathrm{BI}$ can be performed.

\section{Materials and methods}

Soils

Three surface soils (Soils 1-3) collected from Beijing area were used in this study. The soils are of similar properties with respect to $\mathrm{pH}, \mathrm{CaCO}_{3}$ equivalent, organic matter content etc. (Table 1), but located in vegetable field, nursery of young plants, and roadside, respectively. These soils were selected to investigate the difference or bioavailability of trace elements in soils of similar type, which could not be distinguished by correlation analysis.

The soils were air-dried, crushed with a good mallet, and sieved through a 2-mm nylon screen. Precautions were taken to avoid contamination during sampling, drying, crushing and storage. Soil properties of $\mathrm{pH}$, organic carbon content and equivalent of $\mathrm{CaCO}_{3}$ were determined by using standard methods (Lao, 1988). Total content of the trace elements was obtained by ICP-AES (Jarrel-Ash $1155 \mathrm{~V}$ multichromator) after samples were digested with $\mathrm{HNO}_{3} / \mathrm{HClO}_{4} / \mathrm{HF}$ under high pressure conditions (Shan and Chen, 1992). 
Table l. Some properties of the three soil samples used pot experiments

\begin{tabular}{lccc}
\hline Property & \multicolumn{3}{c}{ Soils } \\
\cline { 2 - 4 } & Soil 1 & Soil 2 & Soil 3 \\
\hline $\mathrm{pH}$ & $7.9 \pm 0.1$ & $7.7 \pm 0.1$ & $7.7 \pm 0.1$ \\
Org. C, $\mathrm{g} \mathrm{kg}^{-1}$ & $14.6 \pm 1.1$ & $8.9 \pm 0.5$ & $20.4 \pm 1.3$ \\
$\mathrm{CaCO}_{3}, \mathrm{~g} \mathrm{~kg}^{-1}$ & $59.8 \pm 4.7$ & $25.8 \pm 2.1$ & $41.8 \pm 3.6$ \\
Texture & Clay loam & Sandy loam & Loamy sand \\
Total $\left(\mathrm{mg} \mathrm{kg}^{-1}\right)$ & & & \\
$\mathrm{Cu}$ & $40.9 \pm 2.8$ & $32.9 \pm 2.4$ & $23.4 \pm 1.6$ \\
$\mathrm{Mn}$ & $479.4 \pm 17$ & $438.2 \pm 19$ & $446.5 \pm 9.9$ \\
$\mathrm{Zn}$ & $113 \pm 6.2$ & $77.5 \pm 3.2$ & $104.3 \pm 4.4$ \\
$\mathrm{Ni}$ & $29.8 \pm 2.5$ & $29.0 \pm 2.1$ & $24.0 \pm 1.8$ \\
$\mathrm{Co}$ & $18.2 \pm 1.3$ & $18.2 \pm 1.1$ & $15.4 \pm 0.9$ \\
$\mathrm{~Pb}$ & $12.9 .8 \pm 7.1$ & $103 \pm 5.3$ & $106.7 \pm 3.6$ \\
$\mathrm{Cr}$ & $64.8 \pm 3.8$ & $62.6 \pm 3.5$ & $55.5 \pm 3.6$ \\
$\mathrm{~V}$ & $69.8 \pm 4.1$ & $72.8 \pm 4.4$ & $61.5 \pm 3.1$ \\
\hline
\end{tabular}

all analyses were done in three replications.

\section{Selection of extractants}

The numerous extractants used in literature can be grouped into several types according to their properties and reaction mode, i.e. neutral salt solution (e.g. $\mathrm{NH}_{4} \mathrm{OAc}, \mathrm{CaCl}_{2}, \mathrm{NH}_{4} \mathrm{NO}_{3}$, etc.), chelating agents (DTPA, EDTA), acid extractants $\left(\mathrm{HCl}, \mathrm{H}_{3} \mathrm{PO}_{4}, \mathrm{HOAc}\right.$, etc.) and reducing agents $\left(\mathrm{NH}_{2} \mathrm{OH} \cdot \mathrm{HCl}\right)$. Of the four types of extractants, neutral salt solutions usually extract extremely small amounts of metals (far less than $1 \%$ of the total content) which can rapidly be replenished from other chemical pools of the element. Changes in total plant content of trace elements caused by neutral salt extraction are insignificant. Therefore, neutral salt solution was not tested, while DTPA $(0.005$ $M$ DTPA + $0.1 M$ TEA + $\left.0.01 M \mathrm{CaCl}_{2}\right), 1 M \mathrm{HCl}$,

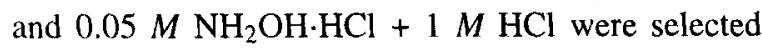
to represent the other three types of extractants. The extraction procedures are given below.

\section{Soil preparation and pot experiment}

Soil preparation includes extraction, washing, $\mathrm{pH}$ adjustment and fertilization of the soil prior to pot experiment. Due to the relatively large amounts of soils needed for potting ( $1 \mathrm{~kg}$ soil per pot, three replications), big bottles ( $5 \mathrm{~L}$ in capacity) were used to hold the extraction mixture (500 $\mathrm{g}$ of soil and 1000 $\mathrm{mL}$ of extractant), which were mixed and shaken on an oscillating shaker for $2 \mathrm{~h}$. After extraction, the sus- pension was subjected to solid-liquid separation by suction filtration. The soil after filtration was washed with distilled-deionized water several times to eliminate the extractant. The washed soil was air-dried and crushed with a wooden mallet.

The three soils were all calcareous with relatively high $\mathrm{pH}$ of 7.9, 7.7 and 7.7, respectively. Since extractions with $\mathrm{HCl}$ or $\mathrm{HCl}+\mathrm{NH}_{2} \mathrm{OH} \cdot \mathrm{HCl}$ might greatly alter $\mathrm{pH}$ levels of these soils, $\mathrm{pH}$ adjustment was necessary. In a preliminary study, $\mathrm{pH}$ changes after extraction and washing were determined. The results showed that soil $\mathrm{pH}$ dropped for about 2.2 units after extraction with $\mathrm{HCl}$ or $\mathrm{HCl}+\mathrm{NH}_{2} \mathrm{OH} \mathrm{HCl}$. Effects of DTPA extraction on soil $\mathrm{pH}$ were not apparent, so $\mathrm{pH}$ adjustment was not performed in this case.

In order to restore soil $\mathrm{pH}$ to its original level, another preliminary experiment was carried out by using $100 \mathrm{~g}$ of the processed soil with graded amounts of $\mathrm{CaO}(0.05,0.1,0.2,0.4,0.6,1.0$, and $2.0 \mathrm{~g}$, respectively). The mixture was moistened to $15 \%$ moisture content on a weight basis and placed in an incubator at $25^{\circ} \mathrm{C}$. Moisture content of the mixture was maintained throughout the incubation period. Soil samples were withdrawn every week up to the sixth week, and the last sample was withdrawn after the ninth week. The $\mathrm{pH}$ was measured in a 1:2.5 (w/v) soil/water suspension. The amounts of $\mathrm{CaO}$ needed to raise soil $\mathrm{pH}$ to the desired levels were calculated.

For pot experiments, $1 \mathrm{~kg}$ of the soil was thoroughly mixed with the calculated amounts of $\mathrm{CaO}$ (only for soils after $\mathrm{HCl}$ and $\mathrm{NH}_{2} \mathrm{OH}$. $\mathrm{HCl}$ treatment). All pots were fertilized and mixed with $\mathrm{NH}_{4} \mathrm{NO}_{3}, \mathrm{KH}_{2} \mathrm{PO}_{4}$, and $\mathrm{K}_{2} \mathrm{SO}_{4}$ in amounts corresponding to $800 \mathrm{mg} \mathrm{N}, 800 \mathrm{mg}$ $\mathrm{K}, 300 \mathrm{mg} P$ and $170 \mathrm{mg} \mathrm{S}$ per pot. The treatments were replicated three times. The soil was then moistened to $15 \%$ moisture content on a weight basis and placed into $1.5-\mathrm{L}$ plastic pots. All pots were incubated in the greenhouse for 3 weeks prior to planting to allow the reaction of lime with soil until stabilization.

After incubation, 30 seeds of rape (Brassica chinensis) and 20 seeds of winter wheat (Triticum aestivum L. ) were sown in each pot. After germination, pots were thinned to 10 plants. Water losses were made up by daily addition of deionized water to maintain the moisture content close to $15 \%$.

The above-ground parts of the plants were harvested 8 weeks after germination. The plant samples were oven-dried at $65^{\circ} \mathrm{C}$ directly after harvest and then ground. Trace metals $(\mathrm{Cu}, \mathrm{Mn}, \mathrm{Ni}, \mathrm{Zn}, \mathrm{Co}, \mathrm{Pb}, \mathrm{Cr}$ and V) were extracted by digestion with conc. $\mathrm{HNO}_{3} /$ conc. $\mathrm{HClO}_{4}$ under high pressure. After digestion, surplus 
$\mathrm{HClO}_{4}$ was removed by boiling to near dryness at 220 ${ }^{\circ} \mathrm{C}$. The residue was then dissolved in several portions of $5 \mathrm{~mL}$ of $1 \mathrm{M} \mathrm{HNO}_{3}$ and make up to $10 \mathrm{~mL}$ volume with deionized water. The total dry matter yields of each pot were also recorded for comparison of plant growth in the treated and untreated soils.

\section{Instrumental analysis}

Nutrient concentrations in the extract solutions were determined simultaneously by ICP-AES (Jarrel-Ash Model 1155 Atom Comp). The operating conditions for the determinations were optimized. The corrections for background shift and spectral interferences were performed.

\section{Results and discussion}

\section{Effects of soil preparation on soil $\mathrm{pH}$ and plant growth}

The three soils showed similar patterns with respect to changes of soil $\mathrm{pH}$ with time after liming, as represented by Soil 1 (Figure 1). Drastic pH changes occurred in the initial three weeks for all grades of liming. After the third week, soil pH remained relatively stable on a higher level till the ninth week when a slight drop of $\mathrm{pH}$ was observed. For this reason the incubation time of soil was determined to be three weeks. It also could be expected that soil $\mathrm{pH}$ would not change significantly during plant growth period of 8 weeks. Based on the results of the preliminary experiment, the actual lime application rates were 7.2, 5.5,5.0 $\mathrm{g} \mathrm{CaO}$ per pot for soils $1-3$, respectively, to restore soil $\mathrm{pH}$ to the original level.

There exists two methods in the literature for calculating plant accumulation of soil nutrients. The commonly used method takes the tissue content of nutrients on dry weight basis to represent plant accumulation (Eriksson, 1989; Hooda and Alloxay, 1993; Shuman and Anderson, 1974; Soon and Bates, 1982). The total amount of plant nutrient accumulation, product of tissue content and dry matter yield, was also in use (Salcedo and Ellis, 1979; Singh and Narwal, 1984). Generally, results obtained by the two methods are similar. But in greenhouse experiments under different conditions, plants often show apparent disparity in growth rate, resulting in drastically different dry matter yields among pots. The nutrient accumulation values obtained by the two methods will differ largely, casting suspicions on any conclusions that can be made. In this study, BI was calculated based on variation in tissue content of the trace elements. In the mean time, the situation of plant growth in each pot was also paid close attention to examine whether the soil preparation procedure caused significant differences in plant growth. No such difference was observed, as evidenced by the dry matter yields recordings (Table 2), indicating that the two experimental crops could maintain a normal growth in the treated soil for a certain period.

\section{Bioavailability of DTPA-extractable fraction}

It is well-realized that a strong linkage exists between bioavailability and the DTPA-extractable trace elements. The significance of DTPA-extractable fraction to plant accumulation was well demonstrated by the BI results. The three soils showed similar results and Soil 1 was selected as an example for discussion (Table 3). Though DTPA removed only a minor fraction (3.09\% on average) of the total content from soil, the plant contents of the nutrients were greatly reduced $(35.8 \%$ for wheat and $15.5 \%$ for rape, average value), resulting in large BI values. The average values of BI of the eight nutrient elements for wheat and rape were 22.7 and 8.9 , respectively. The result clearly proved that the DTPA-extractable trace elements represented the highly available fraction of the total content. When the available resources of this nature were removed by DTPA extraction, nutrient accumulation by plant would inevitably be significantly affected. Wheat seemed to be more dependent on the DTPA-extractable fraction, for the resulting nutrient accumulation reduction in wheat was much more obvious than that in rape (Table 3 ). This was probably because wheat had developed a more effective mechanism to derive nutrients by root-mediated production of chelators such as phytosiderophores (Marschner et al., 1986; Romheld and Marschner, 1990), therefore, greater response of wheat to the DTPA-induced change could be expected.

Variations of BI among different trace elements were also considerable. For wheat, the maximum BI existed for $\mathrm{Cr}$ (50), more than 10 times of the minimum value for $\mathrm{Cu}(3.8)$. For rape, the corresponding values were 22 for $\mathrm{Cr}$ and 2.4 for $\mathrm{Cu}$. Examining data in Table 3 in more detail, it could be found that this drastic variation was mainly caused by the different extractability of the trace elements with DTPA. Only $0.76 \%$ of $\mathrm{Cr}$ was removed by DTPA, while in case of $\mathrm{Cu}$, the proportion removed was $9.4 \%$. Though DTPA has different 


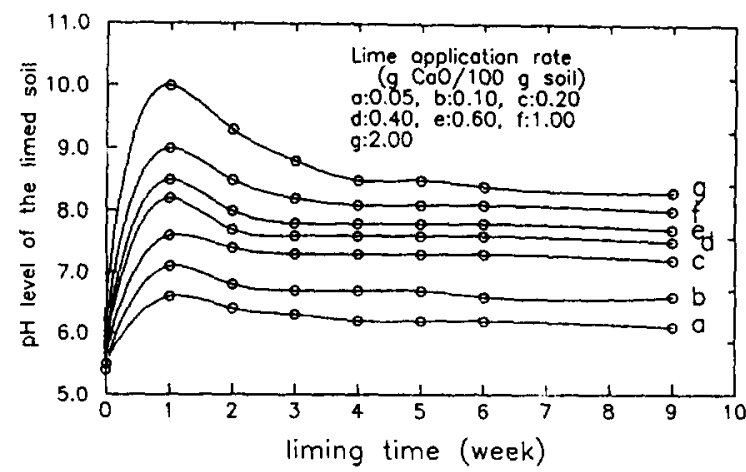

Figure 1. Changes of soil $\mathrm{pH}$ with time under different lime application rates (Soil 1, after $\mathrm{HCl}$ treatment).

Table 2. Comparison of dry matter yields of wheat and rape grown in different soils

\begin{tabular}{|c|c|c|c|c|c|c|c|c|c|c|c|c|}
\hline \multirow{3}{*}{$\begin{array}{l}\text { Dry Matter } \\
\text { yields }\end{array}$} & \multicolumn{4}{|c|}{ Soil 1} & \multicolumn{4}{|c|}{ Soli 2} & \multicolumn{4}{|c|}{ Soil 3} \\
\hline & \multirow[t]{2}{*}{ Untreated } & \multicolumn{3}{|c|}{ Treated } & \multirow[t]{2}{*}{ Untreated } & \multicolumn{3}{|c|}{ Treated } & \multirow{2}{*}{ Untreated } & \multicolumn{3}{|c|}{ Treated } \\
\hline & & $\overrightarrow{\mathrm{DTPA}}$ & $\mathrm{HCl}$ & $\mathrm{NH}_{2} \mathrm{OH}, \mathrm{HCl}$ & & DTPA & $\mathrm{HCl}$ & $\mathrm{NH}_{2} \mathrm{OH}, \mathrm{HCl}$ & & DTPA & $\mathrm{HCl}$ & $\mathrm{NH}_{2} \mathrm{OH}, \mathrm{HCl}$ \\
\hline Wheat (g/pot) & 4.42 & 4.57 & 4.26 & 4.28 & 5.09 & 4.90 & 4.64 & 4.75 & 4.80 & 4.76 & 4.93 & 4.90 \\
\hline Rape (g/pot) & 3.76 & 3.54 & 3.79 & 3.64 & 3.68 & 3.66 & 3.30 & 3.63 & 3.49 & 3.47 & 3.66 & 3.34 \\
\hline
\end{tabular}

${ }^{a}$ Average value of three replicates.

Table 3. BI of the extractable trace elements with different extractants for wheat and rape grown in soil $1^{\text {a }}$

\begin{tabular}{|c|c|c|c|c|c|c|c|c|c|c|c|c|c|c|c|}
\hline \multirow[t]{2}{*}{ Element } & \multicolumn{4}{|c|}{$\begin{array}{l}\text { BI of DTPA-extractable } \\
\text { fraction }\end{array}$} & \multicolumn{5}{|c|}{$\begin{array}{l}\text { BI of } \mathrm{HCl} \text {-extractable } \\
\text { fraction }\end{array}$} & \multicolumn{6}{|c|}{$\begin{array}{l}\mathrm{BI} \text { of } \mathrm{NH}_{2} \mathrm{OH} \cdot \mathrm{HCl}+\mathrm{HCl} \\
\text { extractable fraction }\end{array}$} \\
\hline & $\begin{array}{l}\mathrm{C}_{\mathrm{E}} \\
(\%)\end{array}$ & $\begin{array}{l}\triangle \mathrm{C}_{\mathrm{Pw}} \\
(\%)\end{array}$ & $\begin{array}{l}\triangle \mathrm{C}_{\mathrm{Pr}} \\
(\%)\end{array}$ & BIw & $\mathrm{BI}_{\mathrm{R}}$ & $\begin{array}{l}\mathrm{C}_{\mathrm{E}} \\
(\%)\end{array}$ & $\begin{array}{l}\triangle \mathrm{C}_{\mathrm{Pw}} \\
(\%)\end{array}$ & $\begin{array}{l}\triangle \mathrm{C}_{\mathrm{Pr}} \\
(\%)\end{array}$ & $\mathrm{BIw}$ & $\mathrm{BI}_{\mathrm{R}}$ & $\begin{array}{l}\mathrm{C}_{\mathrm{E}} \\
(\%)\end{array}$ & $\begin{array}{l}\triangle \mathrm{C}_{\mathrm{Pw}} \\
(\%)\end{array}$ & $\begin{array}{l}\triangle \mathrm{C}_{\mathrm{Pr}} \\
(\%)\end{array}$ & $B I_{W}$ & $\bar{B} I_{R}$ \\
\hline $\mathrm{Cu}$ & 9.4 & 36.0 & 22.1 & $3.8 \pm 0.4$ & & 13.0 & 13.5 & 48.0 & $1.0 \pm 0.1$ & & 38.9 & 28.8 & 60.7 & & \\
\hline $\mathrm{Mn}$ & 1.0 & 30.4 & 18.3 & $29 \pm 3$ & $18 \pm 2$ & 29.8 & 36.2 & 55.0 & $1.2 \pm 0.1$ & $1.8 \pm 0.2$ & 44.0 & 51.5 & 67.8 & $1.2 \pm 0.1$ & $1.5 \pm 0.1$ \\
\hline $\mathrm{Ni}$ & 1.4 & 33.0 & 10.9 & $23 \pm 3$ & $8 \pm 1$ & 8.3 & 21.6 & 36.5 & $2.6 \pm 0.1$ & $4.4 \pm 0.4$ & 17.9 & 29.7 & 61.8 & $1.7 \pm 0.2$ & $3.4 \pm 0.3$ \\
\hline $\mathrm{Zn}$ & 5.7 & 51.5 & 29.8 & $9 \pm 1$ & $5 \pm 0.4$ & 23.7 & 23.7 & 62.6 & $1.0 \pm 0.1$ & $2.6 \pm 0.3$ & 46.5 & 41.9 & 73.0 & $0.9 \pm 0.1$ & $1.6 \pm 0.2$ \\
\hline $\mathrm{Co}$ & 2.6 & 32.7 & 8.5 & $12 \pm 1$ & $3.2 \pm 0.2$ & 9.6 & 16.8 & 35.6 & $1.8 \pm 0.1$ & $3.7 \pm 0.3$ & 18.1 & 28.2 & 62.1 & $1.6 \pm 0.1$ & $3.4 \pm 0.3$ \\
\hline $\mathrm{Pb}$ & 3.0 & 33.3 & 11.6 & $11 \pm 1$ & $3.8 \pm 0.4$ & 19.5 & 13.9 & 36.8 & $0.7 \pm 0.1$ & $1.9 \pm 0.2$ & 34.3 & 30.2 & 41.2 & $0.9 \pm 0.1$ & $1.2 \pm 0.1$ \\
\hline $\mathrm{Cr}$ & 0.8 & 37.6 & 16.4 & $50 \pm 5$ & $22 \pm 3$ & 2.9 & 12.5 & 39.7 & $4.3 \pm 0.4$ & $14 \pm 1.2$ & 6.8 & 28.4 & 61.2 & $4.2 \pm 0.3$ & $9 \pm 1$ \\
\hline V & 0.7 & 31.8 & 6.7 & $44 \pm 4$ & $9 \pm 1$ & 4.3 & 14.5 & 28.6 & $3.4 \pm 0.3$ & $7 \pm 0.8$ & 10.4 & 26.9 & 57.3 & $2.6 \pm 0.3$ & $6 \pm 0.5$ \\
\hline
\end{tabular}

"The extractable trace elements $\left(C_{E}\right)$ are expressed in percentage of the total content of the elments in the untreated soil and plant accumulation reduction of the elements in wheat $\left(\Delta C_{P_{W}}\right)$ and in rape $\left(\Delta C_{P_{T}}\right)$ are expressed in percentage of the total plant content of the elements in the untreated soil. Values of $C_{E}, \Delta C_{P w}$ and $\triangle C_{P_{r}}$ listed in the table are means of the three replicates, $B I$ for wheat $\left(B I_{W}\right)$ and for rape (BI $)$ are the ratio of $\triangle C_{P w}$ to $C_{E}$ and $\triangle C_{P r}$ to $C_{E}$ respectively, along with the standard deviation for the three replicates. $B I$ values $(>5)$ were rounded up to whole numbers.

affinity for different trace elements, the main factor responsible for the variations in extractability should be the different binding of the elements to the various soil constituents (Jeng and Singh, 1993; Shuman, 1985). In comparison, the resulting plant accumulation reduction of the nutrients remained relatively stable. For wheat, the maximum reduction $(51.5 \%$ for $\mathrm{Zn})$ was less than twice of the minimum value ( $30.4 \%$ for $\mathrm{Mn}$ ). The average accumulation reduction was $35.8 \%$ with a standard deviation of $6.7 \%$. This indicated that the proportional contributions of DTPA-extractable fraction to the accumulation of the nutrients by wheat were less likely to be affected by the absolute amount of the fraction present in soils, and plants could have multiple 
accumulation mechanisms to avoid depending excessively on one source or one mode to derive mineral elements.

Though the average values of BI did not differ significantly among the three calcareous soils with similar properties $(22.7,17.6$ and 17.4 on average for wheat; and $8.9,10.0$ and 11.1 for rape), there were large differences among the trace elements. For example, BI values for $\mathrm{Cr}$ and $\mathrm{V}$ (for wheat) in soil 1 were 50 and 44 , respectively; but the corresponding values were 17 and 40 in soil 2, and 29 and 25 in soil 3. These variations might be attributed to many specific factors inherent in different soils.

\section{Bioavailability of $\mathrm{HCl}$-extractable fraction}

The main objective for developing the BI method was to give a clear differentiation of various extractants with respect to the quantitative nature of bioavailability of the extractable trace elements. The objective was somewhat achieved when BI values of the $\mathrm{HCl}$-extractable fraction were compared with those of DTPA. Again, the first look was given to soil 1 (Table $3)$. Though $\mathrm{HCl}$ removed much more elements $(13.9 \%$ of the total content, average value of the eight trace elements) from the soil than DTPA (3.09\% on average), the resulting plant accumulation reduction of the nutrients was not so much, and even less in case of wheat (19.1\% for $\mathrm{HCl}$ compared with $35.8 \%$ for DTPA, average value). For wheat, the corresponding $\mathrm{BI}$ values were 2.0 and 22.7 , respectively, for $\mathrm{HCl}$-extractable and DTPA-extractable trace elements. It was clear that nutrient accumulation by wheat was more likely to be related to DTPA-extractable fractions than $\mathrm{HCl}$ extractable fractions. These results might further indicate the significance of chelation as the main mechanism for mobilization and acquisition of mineral elements in calcareous soils in particular for wheat. The lower BI values of $\mathrm{HCl}$-extractable trace elements in calcareous soils is understandable from the fact that the root-mediated $\mathrm{pH}$ changes, usually $0.5-2.0 \mathrm{pH}$ units (Hedley et al., 1982; Liu et al., 1990; Smith and Pooley, 1989), cannot match the drastic $\mathrm{pH}$ changes from the original soil $\mathrm{pH}$ to the environment of $1 \mathrm{M} \mathrm{HCl}$ at $\mathrm{HCl}$ extraction, leading to the release of nutrients associated with carbonates or other $\mathrm{HCl}$-soluable minerals, which are generally not available to plants. But the root-excreted chelates do not differ largely from synthetic chelates in their properties, and sometimes the former may be even more effective in activating and transporting metal ions (Bomheld, 1991), so the higher BI values of DTPA-extractable trace elements can be expected.

Genotypical differences were also found in bioavailability of $\mathrm{HCl}$-extractable fractions, however, in a different way compared with DTPA extractable fractions. The average BI value of the eight trace elements for rape was 4.8 (soil 1) and the average nutrient accumulation reduction was $42.8 \%$, more than twice of the corresponding values for wheat, just opposite of the situations caused by DTPA extraction. These results reflected the divergent adaptations of different plants to nutrient deficiency. While the graminaceous plants (such as wheat) developed a very effective mechanism to derive nutrients by chelation (Harschner et al., 1986), the rape plants seemed to be more capable of satisfing its need by adjusting the rhizosphere $\mathrm{pH}$ levels (Moorby et al., 1988). Therefore, $\mathrm{HCl}$ extraction could exert a greater influence on nutrient accumulation by rape than that by wheat.

Variations of BI values among trace elements also existed, but were not as drastic as after DTPA extraction. For wheat, the range of BI was $0.7-4.3$; and for rape, the range was 1.8-14. Similarly, larger BI values generally corresponded to lower extractability, e.g. $\mathrm{HCl}$ removed the least fraction of $\mathrm{Cr}(2.9 \%)$, and led to the largest BI values (4.3 and 14 for wheat and rape, respectively). It was notable that several BI values around 1 appeared in the table, and the minimum was 0.7 for $\mathrm{Pb}$ in wheat, suggesting that the $\mathrm{HCl}$-extractable trace elements may be equal or even less available than the average level of the total soil content. Because soil nutrients are largely comprised of unavailable forms (e.g. trace elements fixed in crystal lattice of the resistant primary or secondary minerals), there must exist some highly available forms in soils to compensate for the unavailable forms to attain an average $\mathrm{BI}$ value of 1 and these forms cannot be removed by $\mathrm{HCl}$. As stated above, DTPA should extract a substantial part of these forms.

Similar results has been achieved with the two other calcareous soils (soils 2 and 3). Though BI values of some nutrients showed significant fluctuations (e. g. BI values for $V$ were $3.4,2.0$ and 4.4 , respectively, for the three soils for wheat, and those for Cu varied from 1.5 3.7 for rape), the average values were similar among the soils. For wheat, the mean values of BI were 2.0,1.9 and 2.4, respectively; and for rape, the corresponding values were $4.8,4.1$ and 3.7 . 
BI values of $\mathrm{NH}_{2} \mathrm{OH} \cdot \mathrm{HCl}$ in $\mathrm{I} \mathrm{M} \mathrm{HCl}$ extractable trace elements

Because reducing agents will not react effectively in neutral or alkaline media, their combination with acid is necessary in practical application (Tessier et al., 1979). Consequently, the extraction results are the sum of two fractions: acid-soluble and reducible fractions. In this study, to simplify the relationship, the reducing agent $\mathrm{NH}_{2} \mathrm{OH} \cdot \mathrm{HCl}$ was loaded in $1 \mathrm{M} \mathrm{HCl}$, and the extraction was performed under the same conditions. The effects of $\mathrm{NH}_{2} \mathrm{OH} \cdot \mathrm{HCl}$ could be assessed by comparing the results of the two kinds of extractions (Table $3)$.

The extractability of all the eight trace elements in soil 1 increased significantly due to addition of $\mathrm{NH}_{2} \mathrm{OH} \cdot \mathrm{HCl}$. The average percentage $(27.1 \%)$ of the trace elements extractable with $\mathrm{NH}_{2} \mathrm{OH} \cdot \mathrm{HCl}+\mathrm{HCl}$ was almost twice of the value $(13.9 \%)$ extractable with $\mathrm{HCl}$ alone. Accordingly, significant increases in the reduction of nutrient accumulation by plant were observed. On average, the accumulation reduction of wheat increased from $19.1 \%$ to $33.1 \%$, and from $42.8 \%$ to $60.6 \%$ for rape. This indicated that a substantial fraction of the nutrients existed in the reducible forms or occluded in the reducible Fe-Mn oxides (Tessier et al., 1979 ) in the investigated soils this fraction was of some significance to plant nutrient acquisition (Zhang and Cao, 1992). It also could be noted that the plant accumulation reduction did not increase in the same proportion as compared with nutrient extractability, leading to lowering of the BI values. Most trace elements showed a drop in their $\mathrm{BI}$ values from $\mathrm{HCl}$ extraction to $\mathrm{NH}_{2} \mathrm{OH} \cdot \mathrm{HCl}+\mathrm{HCl}$ extraction for both wheat and rape. The overall effect was that the average $\mathrm{BI}$ value for wheat decreased from 2.0 to 1.7 , and from 4.8 to 3.4 for rape. These results suggested that the reducible fraction of the trace elements should be regarded as one of the sources capable of providing nutrients to plant, but may be less bioavailable than other sources such as DTPA-extractable and $\mathrm{HCl}$-dissolvable fractions. Similar trend could be found in the other two calcareous soils (unpublished data).

\section{Conclusion}

From the above discussion, it is clear that bioavailability is a complex concept determined by many factors. The BI index and the corresponding experimental method proved to be valuable in the study of the quantitative nature of bioavailability. If the significant plant nutrient accumulation reduction was caused by removing a relatively small fraction of the total nutrient content from soil, it could be certain that this fraction was of high bioavailability. By this way a quantitative measure has been established for evaluation of bioavailability of different extractable fractions. As described above, BI values for DTPA-extractable fraction are much higher than those for $\mathrm{HCl}$ or $\mathrm{HCl}$ $+\mathrm{NH}_{2} \mathrm{OH} \cdot \mathrm{HCl}$ extractable fractions. Therefore, the quantitative differentiation among the extractants with respect to nutrient bioavailability has been achieved. The relative importance of a particular extractable fraction gave some implications on the mechanisms of nutrient accumulation by plant, e.g. the higher BI values of DTPA-extractable fraction highlighted the significant role that chelation action might play in plant nutrient acquisition. Besides its quantitative characteristic, BI also exhibits some specific nature. Wheat and rape showed genotypical differences in their response to the same soil treatment. Variations in BI values among trace elements and soils are also apparent. Though the variations among trace elements can be largely attributed to the different extractability of the elements, factors responsible for the variations among soils are still not clear. These unpredictable variations may greatly lower the degree of correlation in many cases.

\section{Acknowledgement}

This work was funded by the National Natural Science Foundation of China.

\section{References}

Alegria A, Barbera R, Boluda R, Errecalde F, Farre R and Lagarda $\mathrm{M} J 1991$ Environmental $\mathrm{Cd}, \mathrm{Pb}$ and $\mathrm{Ni}$ contamination: possible relationship between soil and vegetable content. Fresenius J. Anal. Chem. 339, 654-657.

Darrah P R 1993 The rhizosphere and plant nutrition: a quantitative approach. Plant and Soil 155/156, 1-20.

Davies B E 1992 Inter-relationships between soil properties and the uptake of $\mathrm{Cd}, \mathrm{Cu}, \mathrm{Pb}$ and $\mathrm{Zn}$ from contaminated soils by radish. Water Air Soil Pollut. 63, 331-342.

Duangpatra P, Sims J L and Ellis J H 1979 Estimating plant-available Mn in selected Kentucky soils. Soil Sci. 127, 35-40.

Dudka S and Chlopecka A 1990 Effect of solid-phase speciation on metal mobility and phytoavailability in sludge-amended soil. Water Air Soil Pollut. 51, 153-160. 
Eriksson J E 1989 The influence of pH. soil type and time on adsorption and uptake by plants of $\mathrm{Cd}$ added to the soil. Water Air Soil Pollut. 48, 317-335.

He Q B and Singh B R 1994 Crop uptake of Cd from phosphorus fertilizers: II. relationship with extractable soil Cd. Water Air Soil Pollut. 74, 267-280.

He X, Taylor R W, Shuford J W, Tadesse W and Adriano D C 1991 Corparison of extractants for available sludge-borne metals: A residual study. Water Air Soil Pollut. 57-58, 913-922.

Hedley M J, Nye P H and White R E 1982 Plant induced changes in the rhizosphere of rape Brassica napus var. Emerald seedlings. II. The origin of the $\mathrm{pH}$ change. New Phytol. 91, 31-44.

Hooda P S and Alloway B J 1993 Effects of time and temperature on the bioavailalbility of $\mathrm{Cd}$ and $\mathrm{Pb}$ from sludge-amended soils. J. Soil Sci. 44, 97-110

Hoyt P B and Nyborg M 1971 Toxic metals in acid soil: II. estimation of plant available Mn. Soil Sci. Soc. Am. Proc. 35, 241-244.

lyengar S S, Martens D C and Miller W P 1981 Distribution and plant availability of soil zinc fractions. Soil Sci. Soc. Am. J. 45, 735-739.

Jeng A S and Singh B R 1993 Partitioning and distribution of cadmium and zinc in selected cultivated soils in Norway. Soil Sci. 240-249.

Khamparia R S, Sharma S B and Rathore G S 1994 Suitability of soil test methods and response in wheat to zinc in some Alfisols and Vertisols. J. Ind. Soc. Soil Sci. 42, 88-92.

Lao J S 1988 Handbook for Soil Agricultural and chemical Analysis. pp 101, 236, 386. Agriculture Press, Beijing, China.

Levesque $\mathrm{M}$ and Mathur S P 1988 Soil tests for $\mathrm{Cu}, \mathrm{Fe}, \mathrm{Mn}$ and $\mathrm{Zn}$ in Histosols: 3 . A comparison of eight extractants for measuring active and reserve forms of the trace elements. Soil Sci. 145, 215-221.

Lindsay W L and Norvell W A 1978 Development of a DTPA soil test for $\mathrm{Zn}, \mathrm{Fe}, \mathrm{Mn}$ and $\mathrm{Cu}$. Soil Sci. Soc. Am. J. 42, 421-428.

Liu Z Y, Shi W M and Fan X H 1990 The rhizosphere effects of phosphorus and iron in soils. In Trans. 14th Int. Congr. Soil Sci., Kyoto, Japan, August 1990. Vol II. pp 147-152.

Marschner H, Romheld V and Kissel M 1986 Different strategies in higher plants in mobilisation and uptake of iron. J. Plant Nutr. 9, 695-713.

Moorby H, White R E and Nye P H 1988 The influence of phosphate nitrition on $\mathrm{H}$ ion efflux from the roots of young rape plants. Plant and Soil 105, 247-256

Randall G W, Schulte E E and Corey R B 1976 Correlation of plant $\mathrm{Mn}$ with extractable soil $\mathrm{Mn}$ and soil factors. Soil Sci. Soc. Am. J. $40,282-287$.
Romheld V 1991 The role of phytosiderophores in acquisition of iron and other micronutrients in graminaceous species: An ecological approach. Plant and Soil 130, 127-134.

Romheld V and Marschner H 1990 Genotypical differences among gramineous species in release of phytosiderophores and uptake of iron phytosiderophores. Plant and Soil 123, 147-153.

Salcedo I H and Ellis B G 1979 Mn labile pool and plant uptake Soil Sci. 127, 227-234.

Saucerbeck D R 1991 Plant, element and soil properties governing uptake and availability of heavy metals derived from sewage sludge. Water Air Soil Pollut. 57/58, 227-237.

Shan X Q, Chen B, Jin L Z, Zhen Y, Hou X P and Mou S F 1992 Determination of sulfur fractions in soils by sequential extraction. inductively coupled plasma-optical emission spectroscopy, and ion chromatography. Chem. Spec. Bioavail. 4, 97-102.

Shuman L M 1985 Fractionation method for soil microelements. Soil Sci. 140, 11-22.

Shuman L M and Anderson O E 1974 Evaluation of six extractants for their ability to predict $\mathrm{Mn}$ concentrations in wheat and soybeans. Soil Sci. Soc. Am. Proc. 38, 788-790.

Singh B R and Narwal R P 1984 Plant availability of heavy metals in a sludge-treated soil: II. Metal extractability compared with plant metal uptake. J. Environ. Qual. 13, 344-349.

Smith W H and Pooley A S 1989 Red spruce rhizosphere dynamics: spatial distribution of aluminum and zinc in the near-root soil zone. For. Sci. 35, 1114-1124.

Soon Y K and Bates T E 1982 Chemical pools of $\mathrm{Cd}, \mathrm{Ni}$, and $\mathrm{Zn}$ in polluted soils and some preliminary indications of their availability to plants. J. Soil Sci. $33,477-488$.

Taylor R W, Ibeabuchi I O, Sistani K R and Shuford J W 1993 Heavy metal concentration in forage grasses and extractability from some acid mine spoils. Water Air Soil Pollut. 68, 363-372.

Tessier A, Campbell P G C and Bisson M 1979 Sequential extraction procedure for the specification of particulate trace metals. Anal. Chem. 51, 844-850.

Warden B T and Reisenauer H H 1991 Fractionation of soil Mn foras important to plant availability. Soil Sci. Soc. Am. J. 55, 345-349.

Xian X F and Shokohifard G I 1989 Effect of pH on chemical forms and plant availability of $\mathrm{Cd}, \mathrm{Zn}, \mathrm{Pb}$ in polluted soils. Water Air Soil Pollution 45, 262-273.

Zhang F S and Cao Y P 1992 Rhizosphere dynamics and plant nutrition. Acta Pedol. 29, 239-250.

Section editor: $L V$ Kochian 